\title{
HUBUNGAN TINGKAT PENERAPAN PRINSIP PENGEMBANGAN MASYARAKAT DENGAN KEBERHASILAN PROGRAM CSR PT PERTAMINA
}

\author{
Relationship Between The Principles Implementation Level of Community Development with \\ The Success of CSR Programs PT Pertamina
}

\author{
Mutmainna*) dan Titik Sumarti \\ Departemen Sains Komunikasi dan Pengembangan Masyarakat, Fakultas Ekologi Manusia, IPB
}

*)Email : ina.mutmainna@gmail.com

\begin{abstract}
The Implementation of Corporate Social Responsibility (CSR) is a must for the company as an expression of concern for the social life and environment in addition to pursuit of economic profit. One form of implementation of CSR is the empowerment of local economy. This study aims to analyze the relationship between the principles implementation level of community development with the success of CSR program PT Pertamina. The principles implementation level of community development measured indicators of the program suitability to the participants needs, mentoring programs and participation in local economic development programs. Attainment the principles implementation level of community development indicators are expected relate to the success of CSR programs PT Pertamina that measured from the participation level in KUB, the individual income level in one year, and diversity of income levels program participants. This research conducted in Balongan and Majakerta village, Indramayu using survey methods with 60 respondents. Results showed (1) the principles implementation level of community development is at a medium level; (2) the participation level in KUB is at the level of non-participation (low); the individual income level is at the low and medium income level; diversity of income levels are at a high level; (3) the principles implementation level of community development is positively related to the participation level in KUB; not positively related to the individual income level; not positively related to the diversity of income levels program participants.
\end{abstract}

Keywords : CSR, participation level, the principles implementation level of community development, the success level of CSR programs

\begin{abstract}
ABSTRAK
Penerapan (CSR) merupakan suatu keharusan bagi perusahaan sebagai ungkapan kepeduliannya terhadap kehidupan sosial dan lingkungan atas pencapaian keuntungan ekonomi. Salah satu bentuk penerapan CSR adalah pemberdayaan ekonomi lokal. Penelitian ini untuk menganalisis hubungan tingkat penerapan prinsip pengembangan masyarakat dengan keberhasilan program CSR PT Pertamina. Penerapan prinsip tingkat pengembangan masyarakat diperhitungkan melalui indikator kesesuaian program dengan kebutuhan peserta, bimbingan program dan partisipasi dalam program pengembangan ekonomi lokal. Indikator pencapaian Penerapan prinsip pengembangan masyarakat dalam program pemberdayaan ekonomi lokal, dilihat dari: tingkat partisipasi peserta dalam KUB, tingkat pendapatan peserta program dalam setahun dan tingkat keragaman nafkah peserta program. Penelitian dilakukan di Desa Balongan dan Majakerta, Indramayu menggunakan metode survey dengan 60 responden. Hasil penelitian ini menunjukkan (1) tingkat penerapan prinsip pengembangan masyarakat berada pada tingkat medium; (2) tingkat partisipasi non peserta dalam KUB masih rendah; tingkat pendapatan individu berada pada tingkat pendapatan rendah dan menengah; keberagaman tingkat pendapatan masih tinggi; (3) tingkat penerapan prinsip pengembangan masyarakat berhubungan positif dengan tingkat partisipasi di KUB; berhubungan negatif dengan tingkat pendapatan individu; berhubungan negatif dengan keragaman tingkat pendapatan peserta program.
\end{abstract}

Kata kunci: CSR, tingkat keberhasilan program CSR, tingkat partisipasi, tingkat penerapan prinsip pengembangan masyarakat

\section{PENDAHULUAN}

\section{Latar Belakang}

Masyarakat yang bertempat tinggal di Desa Balongan dan Desa Majakerta Kecamatan Balongan Kabupaten
Indramayu adalah masyarakat yang termasuk dalam Ring 1 wilayah operasi kilang minyak PT Pertamina Balongan. Dari pemaparan pendamping lapang CSR PT Pertamina di kedua desa tersebut, diperoleh informasi bahwa kondisi sosial ekonomi masyarakat pada umumnya belum mencapai kesejahteraan. Masyarakat disekitar 
perusahaan masih banyak yang berada pada kondisi miskin karena tidak memadainya lapangan pekerjaan, tingkat pendapatan yang masih rendah, kapasitas SDM yang lemah, kurangnya pendidikan, dan tidak adanya akses yang diberikan untuk mengelola sumber daya yang ada. Pada tahun 2010 terjadi konflik antara masyarakat dan perusahaan yang mengakibatkan kerugian yang sangat besar bagi PT Pertamina. Permasalahan tersebut dilandasi ketidakpuasan masyarakat terhadap perusahaan yang tidak memedulikan kondisi sosial ekonomi mereka. Tidak adanya akses terhadap lapangan kerja menjadi penyebab utama ketidakpuasan masyarakat.

Hal tersebut akhirnya berupaya diselesaikan dan diperbaiki kembali oleh PT Pertamina dengan salah satu jalan yakni dilaksanakannya program Corporate Social Responsibility (CSR) yang berfokus pada pemberdayaan ekonomi lokal. Program pemberdayaan ekonomi lokal tersebut merupakan salah satu program, khususnya di dua desa yakni Desa Balongan, dan Desa Majakerta, meliputi kegiatan budidaya lele, perikanan tangkap, dan peternakan. Program pemberdayaan ekonomi lokal merupakan salah satu kegiatan pemberdayaan masyarakat yang dilakukan oleh CSR PT Petamina bekerjasama dengan P4W (Pusat Pengkajian, Pengembangan, dan Perencanaan Wilayah) LPPM IPB. Upaya pemberdayaan masyarakat tersebut merupakan salah satu strategi untuk menjaga keberlanjutan PT Pertamina dalam menjalankan usahanya. Program pemberdayaan ekonomi lokal tersebut sangat diharapkan dapat memberikan manfaat bagi berbagai pihak sehingga terbangun sinergi yang baik, khususnya dalam memperbaiki kondisi sosial ekonomi masyarakat.

Pelaksanaan program CSR sudah semestinya dilakukan oleh PT Pertamina yang merupakan salah satu perusahaan pengolahan minyak dan gas bumi negara di Indonesia yang termasuk dalam BUMN. Komitmen penyediaan dana untuk program CSR Pertamina adalah sebesar 1\% dari prognosis laba perseroan dengan pembagian realisasi $80 \%$ dana untuk program CSR perusahaan yang direncanakan dan $20 \%$ dana untuk program yang sifatnya responsif (EC1) (PT Pertamina 2011). Oleh karena itu, PT Pertamina telah menerapkan beberapa program CSR bagi masyarakat desa binaan sekitar perusahaan mereka. Salah satu program yang telah dilaksanakan PT Pertamina yakni program bina desa mandiri yang salah satunya berfokus pada program pemberdayaan ekonomi lokal.

Beberapa perusahaan besar yang bergerak di bidang pengelolaan sumber daya alam telah mampu mengembangkan bentuk-bentuk kegiatan CSR-nya dengan baik, namun beberapa perusahaan lainnya ada juga yang belum mampu mengefektifkan pelaksanaan kegiatan CSR sehingga tercapai taraf keberhasilan. Hal ini didorong oleh beberapa faktor, di antaranya adalah kegiatan yang dilakukan oleh perusahaan tidak menerapkan konsepkonsep pengembangan masyarakat misalnya tidak sesuai dengan kebutuhan masyarakat, tidak ada pendampingan dan tidak dapat meningkatkan partisipasi masyarakat untuk ikut menyukseskan program-program CSR tersebut. Faktor tersebut pada akhirnya menyebabkan pelaksanaan kegiatan CSR tidak mampu berkembang secara efektif untuk mencapai tujuannya, yakni memberdayakan masyarakat dan lingkungannya agar kesejahteraan itu tercapai (Rahmawati, 2010).

Menurut Mapisangka (2009), implementasi program CSR diarahkan pada tercapainya peningkatan kesejahteraan hidup masyarakat di sekitar perusahaan. Hal ini karena perusahaan dan masyarakat pada dasarnya merupakan kesatuan elemen yang dapat menjaga keberlangsungan perusahaan itu sendiri. Lebih jauh lagi dalam lingkungan bisnis perusahaan, masyarakat disekitar perusahaan pada dasarnya merupakan pihak yang perlu mendapatkan apresiasi. Apresiasi ini dapat diwujudkan dalam bentuk peningkatan kondisi sosial ekonomi mereka melalui kegiatan pemberdayaan masyarakat yang dilakukan oleh kegiatan CSR perusahaan. Implementasi CSR merupakan perwujudan komitmen yang dibangun oleh perusahaan yang bertujuan untuk memberikan kontribusi pada peningkatan kualitas kehidupan masyarakat. Tanggung jawab sosial perusahaan tersebut dapat dikatakan sebagai timbal balik perusahaan kepada masyarakat dan lingkungan sekitarnya karena perusahaan telah mengambil keuntungan atas masyarakat dan lingkungan sekitarnya (Susiloadi 2008). Salah satu aturan dasar dari pemerintah Indonesia yang membuat konsep CSR tersebut harus direalisasikan dan diimplementasikan oleh setiap perusahaan di Indonesia karena diberlakukannya Undang-Undang tentang Perseroan Terbatas (UU-PT) yang salah satu pasal dalam UU-PT 2007 tersebut, yakni dalam pasal 74 ayat 1 , disebutkan bahwa setiap perseroan yang menjalankan kegiatan usaha yang berkaitan dengan pengelolaan sumber daya alam diwajibkan untuk melaksanakan kegiatan tanggung jawab sosial dan lingkungan. Berdasarkan Undang-Undang tersebut, setiap perusahaan kini wajib mengeluarkan dana perusahaannya untuk mengimplementasikan dan membuat program CSR yang ditujukan bagi seluruh stakeholder terkait.

Bentuk tanggung jawab sosial perusahaan dapat dijelaskan melalui berbagai bentuk aktivitas perusahaan seperti program pembangunan atau pengembangan komunitas, pelayanan komunitas, dan pemberdayaan komunitas. Beberapa perusahaan besar telah mampu mengembangkan bentuk-bentuk kegiatan CSR-nya dengan baik melalui berbagai macam program. Seringkali program CSR yang dilakukan hanya berlandaskan prinsip partisipasi seluruh stakeholder demi tercapainya keberhasilan program. Padahal keberhasilan suatu program dapat tercapai secara efektif bila dalam pelaksanaannya menerapkan beberapa prinsip pengembangan masyarakat yang dapat dilihat dari sejauhmana program tersebut telah sesuai dengan kebutuhan masyarakat dan menggunakan kealihan dari luar yang diperlukan (pendampingan). Tidak hanya itu program juga harus bersifat partisipatif. Ketika suatu program CSR dapat dilaksanakan berdasarkan prinsip-prinsip pengembangan masyarakat dan terjadi partisipasi aktif dalam pelaksanaannya maka program tersebut diharapkan mencapai keberhasilan sehingga memberikan manfaat bagi kehidupan masyarakat. Oleh karena itu, penting untuk mengkaji hubungan tingkat penerapan prinsip pengembangan masyarakat dengan keberhasilan program CSR PT Pertamina.

\section{Rumusan Masalah}

Corporate Social Responsibility (CSR) menjadi unsur penting bagi perusahaan dalam menjamin keberlanjutan bisnisnya dan merupakan wujud tanggungjawab sosial perusahaan terhadap sosial dan lingkungannya atas dampak operasional yang telah dilakukan. Industri yang sangat menggantungkan kegiatan operasionalnya kepada sumber daya alam ini telah memiliki kesadaran akan dampak 
operasionalnya terhadap lingkungan dan masyarakat sekitar. Hal tersebut terbukti dengan kerja keras PT Pertamina dalam melaksanakan berbagai program CSR dengan baik yang bertujuan untuk memberikan manfaat terhadap masyarakat di berbagai desa binaannya khususnya di Desa Balongan dan Desa Majakerta. PT Pertamina telah berupaya melaksanakan program CSR-nya berlandaskan prinsip-prinsip pengembangan masyarakat. Namun belum diketahui sejauhmana tingkat penerapan prinsip-prinsip pengembangan masyarakat yang dilakukan PT Pertamina pada program pemberdayaan ekonomi lokal. Oleh karena itu, pertanyaan yang akan dikaji lebih lanjut adalah sejauhmana tingkat penerapan prinsip pengembangan masyarakat dalam program pemberdayaan ekonomi lokal.

Pelaksanaan program CSR PT Pertamina bekerjasama dengan P4W LPPM IPB, fokus pada program pemberdayaan ekonomi lokal, dan berupaya menerapkan prinsip-prinsip pengembangan masyarakat. Hal tersebut tentunya dilakukan demi tercapainya keberhasilan program. Program CSR pemberdayaan ekonomi lokal telah memasuki tahun keempat, dan dalam pelaksanaannya diharapkan memberikan pengaruh terhadap tingkat partisipasi peserta dalam KUB, tingkat pendapatan peserta program dalam setahun dan tingkat keragaman nafkah peserta program. Namun belum diketahui sejauhmana keberhasilan program CSR dalam program pemberdayaan ekonomi lokal yang telah dicapai PT Pertamina. Oleh karena itu, menjadi penting untuk dianalisis sejauhmana keberhasilan program CSR PT Pertamina.

PT Pertamina berusaha menjaga keberlanjutan perusahaannya dengan jalan melaksanakan tanggung jawabnya untuk memberikan manfaat kepada seluruh stakeholder terkait. Hal tersebut khususnya ditujukan pada masyarakat desa binaannya melalui berbagai program CSR misalnya program pelatihan dan bantuan modal usaha untuk beternak, budidaya, pengolahan sumber daya alam, dll. Khusunya di Desa Balongan dan Desa Majakerta, program yang dijalankan yakni budidaya lele, perikanan tangkap dan peternakan. Program tersebut dilaksanakan berdasarkan prinsip-prinsip pengembangan masyarakat sehingga dapat tercapai keberhasilan program CSR. Namun belum diketahui apakah ada hubungan antara tingkat penerapan prinsip-prinsip pengembangan masyarakat dengan keberhasilan program CSR. Oleh karena itu, sangat penting mengkaji bagaimana hubungan tingkat penerapan prinsip pengembangan masyarakat dengan keberhasilan program CSR PT Pertamina.

\section{Tujuan Penelitian}

Tujuan Penulisan Penelitian secara umum adalah untuk menganalisis "Hubungan Tingkat Penerapan Prinsip Pengembangan Masyarakat dengan Keberhasilan Program CSR PT Pertamina" dan secara khusus bertujuan untuk:

1. Menganalisis tingkat penerapan prinsip pengembangan masyarakat dalam program pemberdayaan ekonomi lokal.

2. Menganalisis keberhasilan program CSR PT Pertamina, dilihat dari: tingkat partisipasi peserta dalam KUB, tingkat pendapatan peserta program dalam setahun dan tingkat keragaman nafkah peserta program.

3. Menganalisis hubungan tingkat penerapan prinsip pengembangan masyarakat dengan keberhasilan program CSR PT Pertamina.

\section{Kegunaan Penelitian}

Hasil penelitian ini diharapkan dapat memberi manfaat bagi para pihak yang berminat maupun yang terkait dengan masalah CSR, khususnya kepada :

1. Peneliti untuk menambah pengetahuan dan pengalaman mengenai CSR dan mampu memaknai secara ilmiah fenomena yang terlihat. Sedangkan untuk Civitas Akademika dapat memperoleh koleksi terbaru penelitian yang akan memperkaya perkembagan pengetahuan mengenai CSR.

2. Perusahaan yang dapat dijadikan bahan pertimbangan dan data untuk mengevaluasi penerapan program CSR yang telah dilaksanakan yang berbasiskan pengembangan masyarakat. Selain itu perusahaan dapat memiliki data dan informasi terbaru yang dapat digunakan untuk meningkatkan efektifitas .

3. Masyarakat, dapat memperoleh pengetahuan serta gambaran mengenai tingkat pendidikan masyarakat akibat manfaat program CSR yang telah dilaksanakan.

4. Pemerintah, diharapkan dapat menentukan arah kebijakan dan peraturan mengenai CSR yang lebih bermanfaat bagi masyarakat.

\section{PENDEKATAN TEORITIS}

\section{Corporate Social Responsibility}

Khusnul (2009) mendefenisikan CSR sebagai komitmen perusahaan atau dunia bisnis untuk berkontribusi dalam pengembangan ekonomi berkelanjutan dengan memperhatikan tanggungjawab sosial perusahaan dan menitikberatkan pada keseimbangan antara perhatian terhadap aspek ekonomi, sosial dan lingkungan.

Selain itu, Ambadar (2008) yang mengemukakan bahwa dalam perkembangan CSR telah terjadi pergeseran paradigma pelaksanaan tanggung jawab sosial perusahaan yang meliputi corporate charity, corporate philantrophy, dan corporate citizenship. Dapat diartikan bahwa konsep tanggung jawab sosial perusahaan mulai menuju pada implementasi yang sebenarnya melalui pelaksanaan berbagai program yang berhubungan dengan peningkatan ekonomi, pelestarian lingkungan serta pemberdayaan masyarakat. Hal ini sejalan dengan landasan teoritik dari Elkington (Anatan, 2010) bahwa CSR merupakan wujud kepedulian perusahaan terhadap ekonomi, sosial, dan lingkungan yang didasari tiga prinsip dasar yang meliputi profit, people dan planet (3P).

\section{Prinsip-Prinsip Pengembangan Masyarakat}

Dalam konsep pengembangan masyarakat, keberhasilan suatu program CSR dapat dinilai dari sejauh mana program tersebut dilaksanakan berdasarkan prinsip-prinsip pengembangan masyarakat. Ife (1995) menjelaskan bahwa terdapat dua puluh dua prinsip pengembangan masyarakat. Dari keseluruhan prinsip tersebut, terdapat tiga indikator penting yang harus diterapkan bila diharapkan tercapainya keberhasilan suatu program yaitu kesesuaian dengan kebutuhan masyarakat, pendampingan, dan partisipasi. 


\section{Konsep Partisipasi}

Tingkat keberhasilan sebuah program akan sangat dipengaruhi dari sejauh mana partisipasi suluruh pihak dalam keseluruhan pelaksanaan program dari awal hingga akhir. Nasdian (2014) mendefinisikan partisipasi sebagai proses aktif, inisiatif diambil oleh warga komunitas sendiri, dibimbing oleh cara berfikir mereka sendiri, dengan menggunakan sarana dan proses (lembaga dan mekanisme) dimana mereka dapat menegaskan kontrol secara efektif. Arnstein (1969) menggambarkan delapan tingkatan yang setiap tingkatannya menggambarkan peningkatan pengaruh masyarakat dalam menentukan produk akhir pembangunan, yaitu dari tingkat terendah hingga tertinggi adalah manipulation (manipulasi), therapy (terapi), information (informasi), consultation (konsultasi), placation (penentraman), partnership (kemitraan), delegated power (pelimpahan kekuasaan) dan citizen kontrol (kontrol masyarakat).

\section{Konsep Keberhasilan Program}

Bentuk keberhasilan suatu perusahaan dalam mengimplementasikan program CSR adalah tidak hanya diterimanya perusahaan yang bersangkutan di dalam masyarakat akan tetapi perusahaan tersebut harus dapat berpartisipasi dan berfungsi penuh terhadap kehidupan masyarakat sebagai suatu kesatuan sosial, ekonomi, politik dan teknologi. Menurut Setiawan seperti dikutip Anggraeni (2013), indikator yang dipergunakan untuk mengukur keberhasilan implementasi konsep Corporate Social Responsibility (CSR) adalah partisipasi dari seluruh komunitas yang ada dan keberlanjutan pola kehidupan masyarakat yang bersangkutan yang erat kaitannya dengan tingkat pendapatan serta keragaman nafkah mereka.

\section{Tingkat Pendapatan}

Keberhasilan program dapat dilihat dari tingkat pendapatan masyarakat. Menurut Mubyarto (2000), pendapatan merupakan penerimaan yang dikurangi dengan biayabiaya yang dikeluarkan. Rosika (2011) kembali mengutip penjelasan mengenai pendapatan menurut Badan Pusat Statistik (BPS), yakni perhitungan pendapatan dapat dilakukan dengan menggunakan pengeluaran/konsumsi masyarakat.

\section{Konsep Keragaman Nafkah}

Selain tingkat pendapatan, keberhasilan program juga dapat dilihat dari keragaman atau strategi nafkah masyarakat dalam kehidupan mereka sehari-hari. Dharmawan (2007) mengemukakan bahwa dalam sosiologi nafkah, pengertian strategi nafkah lebih mengarah pada pengertian livelihood strategy (strategi penghidupan) daripada means of living strategy (strategi bertahan hidup). Strategi nafkah adalah taktik dan aksi yang dibangun oleh individu ataupun kelompok dalam rangka mempertahankan kehidupan mereka dengan tetap memperhatikan eksistensi infrastruktur sosial, struktur sosial dan sistem nilai budaya yang berlaku.

\section{Kerangka Pemikiran}

Tujuan dari penelitian ini secara umum adalah menganalisis hubungan tingkat penerapan prinsip pengembangan masyarakat dengan keberhasilan program CSR PT Pertamina Dalam konsep pengembangan masyarakat, keberhasilan suatu program dapat dicapai apabila didasarkan oleh prinsip-prinsip pengembangan masyarakat dalam keseluruhan proses pelaksanaannya. Tingkat penerapan prinsip-prinsip pengembangan masyarakat mencakup sejauhmana program tersebut telah sesuai dengan kebutuhan masyarakat, adanya pendampingan (menggunakan kealihan dari luar yang diperlukan), dan partisipasi juga menjadi hal penting yang harus diperhatikan dalam program pengembangan masyarakat (Ife, 1995). Ketika suatu program CSR dapat dilaksanakan sesuai dengan prinsip-prinsip pengembangan masyarakat maka program tersebut dapat menjamin keberhasilan dalam memberikan manfaat bagi masyarakat. Keberhasilan program CSR yang telah dilaksanakan suatu perusahaan dapat dilihat dari perkembangan kondisi sosial ekonomi masyarakat yang mengikuti program CSR. Perubahan tersebut dispesifikkan dalam lingkup sejauhmana tingkat partisipasi peserta program dalam Kelompok Usaha Bersama (KUB) yang terbentuk berkat hadirnya program pemberdayaan ekonomi lokal. Selain itu, keberhasilan program CSR pemberdayaan ekonomi lokal juga diukur dari tingkat pendapatan dan keragaman nafkah peserta program (memberikan masyarakat peluang dalam memperoleh mata pencaharian lainnya). Tingkat partisipasi peserta program dalam KUB diukur dengan melihat sejauhmana keterlibatan masyarakat dalam keseluruhan proses pelaksanaan KUB. Berkaitan dengan tingkat pendapatan peserta program diukur dengan pengeluaran selama setahun terakhir yang dikeluarkan selama melakukan usaha/pekerjaan. Selanjutnya untuk tingkat keragaman nafkah peserta program diukur dari seluruh kegiatan atau pekerjaan yang dilakukan oleh responden dari program CSR.

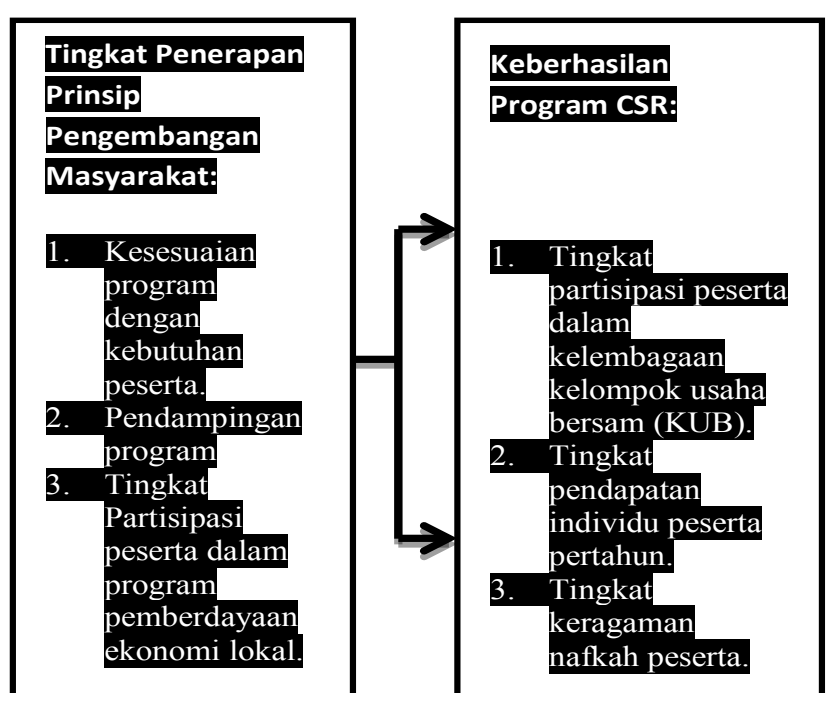

Gambar 1. Kerangka pemikiran

\section{PENDEKATAN LAPANGAN}

\section{Metode Penelitian}

Penelitian ini menggunakan pendekatan kuantitatif dengan metode survei yang didukung oleh data kualitatif. Metode survei dilakukan melalui pengisian kuesioner. Pendekatan kuantitatif ini diharapkan dapat menjawab bagaimana hubungan antara tingkat penerapan prinsip-prinsip pengembangan masyarakat pada program pemberdayaan ekonomi lokal, mencakup kegiatan budidaya lele, perikanan tangkap, dan peternakan dengan keberhasilan 
program yang diukur dari tingkat partisipasi masyarakat dalam Kelompok usaha bersama, tingkat pendapatan dan tingkat keragaman nafkah peserta program di desa sekitar wilayah operasi perusahaan yakni di Desa Balongan dan Desa Majakerta, Indramayu. Pendekatan kualitatif bersifat explanatory research dengan menggunakan teknik wawancara mendalam terhadap informan yang pada penelitian ini menyoroti tokoh masyarakat, pihak perusahaan (pendamping teknis program). Hasil uraian dijelaskan secara deskripsi namun fokus pada hubungan antar variabel untuk menguji hipotesa.

\section{Lokasi dan Waktu Penelitian}

Penelitian ini dilakukan di sekitar wilayah PT Pertamina RU VI Balongan khususnya di Desa Balongan dan Desa Majakerta, Kecamatan Balongan, Kabupaten Indramayu, Jawa Barat. Wilayah ini termasuk dalam wilayah Ring 1 operasi tambang minyak PT Pertamina RU VI Balongan. Pemilihan lokasi penelitian dilakukan secara purposive (sengaja). Berdasarkan informasi terkait dengan keberadaan perusahaan tambang PT Pertamina RU VI yang merupakan salah satu perusahaan yang bergerak di bidang pertambangan dan pengolahan minyak dan gas bumi pada kenyataannya tidak terlepas dari beberapa permasalahan (konflik) yang terkait dengan masyarakat disekitarnya. Hadirnya program CSR pemberdayaan ekonomi lokal yang berfokus pada program budidaya lele, perikanan tangkat dan peternakan bagi masyarakat berhubungan dengan kondisi sosial ekonomi masyarakat yang menjadi peserta program, sehingga menjadi relevan terhadap penelitian hubungan tingkat keberhasilan program CSR dengan kondisi sosial ekonomi peserta program. Waktu penelitian dilaksanakan mulai Bulan Februari hingga Bulan Juni.

\section{Teknik Pengolahan dan Analisis Data}

Informan adalah orang yang termasuk dalam kegiatan ini yang memberikan keterangan mengenai informasi atau data disekitar lingkungannya yang berhubungan dengan penelitian ini. Informan juga dikatakan sebagai pihak yang dapat mendukung keberlangsungan informasi penelitian secara lancar. Informan kunci dalam penelitian ini adalah pelaksana program CSR PT Pertamina, pemerintah desa, dan pihak pendamping program CSR budidaya lele.

Populasi dalam penelitian ini adalah masyarakat Desa Balongan dan Desa Majakerta, Kabupaten Indramayu. Pemilihan responden di wilayah ini dilakukan secara acak untuk semua masyarakat yang menjadi penerima program CSR dari PT Pertamina. Teknik penarikan sampel menggunakan simple random sampling. Karakteristik dari responden yang akan diteliti merupakan populasi masyarakat Desa Balongan dan Desa Majakerta yang termasuk dalam ring 1 RU VI Pertamina Balongan. Unit analisis adalah individu yang mengikuti program pemberdayaan ekonomi lokal yang terdiri atas tiga jenis program berjumlah total 129 orang secara keseluruhan dan mendapatkan bantuan dari program CSR tersebut (Lampiran 3). Program ini terdiri atas program perikanan tangkap yang berjumlah 53 orang, program budidaya lele yang berjumlah 36 orang dan program peternakan yang berjumlah 40 orang dengan usia produktif baik lakilaki maupun perempuan. Berdasarkan hal tersebut, maka peneliti mendata semua penerima program. Kemudian diacak dan didapatkan sebanyak 25 responden yang diambil dari program perikanan tangkap, sebanyak 17 responden yang diambil dari program budidaya lele dan sebanyak 18 responden yang diambil dari program peternakan. Jadi jumlah sampel secara keseluruhan dari ketiga jenis program yang termasuk dalam program pemberdayaan ekonomi lokal adalah 60 responden.

\section{GAMBARAN UMUM DESA BALONGAN DAN DESA MAJAKERTA}

Desa Balongan dan Desa Majakerta merupakan desa yang terletak di Kecamatan Balongan, Kabupaten Indramayu, Jawa Barat. Desa ini merupakan desa yang menjadi binaan PT Pertamina RU VI di bawah pengawasan PT Pertamina. Luas wilayah Desa Balongan yaitu 511 ha. Umumnya lahan digunakan sebagai lahan pemukiman. Selanjutnya, luas wilayah Desa Majakerta yaitu 214 ha. Umumnya lahan digunakan sebagai lahan persawahan. Adapun jumlah kepala keluarga yang terdapat di Desa Balongan sebanyak $1657 \mathrm{KK}$ dan jumlah kepala keluarga yang terdapat di Desa Majakerta sebanyak 1294 KK.

\section{Kondisi Sosial dan Ekonomi}

Masyarakat Desa Balongan mayoritas bermata pencaharian sebagai wiraswasta sebanyak 1017 orang, buruh migran sebanyak 456 orang, petani sebanya 487 orang, buruh tani sebanyak 98 orang, dan selebihnya merupakan pedagang keliling, nelayan, peternak, PNS, montir, TNI, POLRI, pengusaha kecil dll. Data tersebut sejalan dengan pemanfaatan lahan di Desa Balongan yang tidak terfokus pada lahan persawahan. Kondisi tersebut cukup berbeda dengan kondisi ekonomi di Desa Majakerta. Desa ini memiliki lahan persawahan yang sangat luas, hanya saja berdasarkan informasi dari kepala desa, bahwa area persawahan di daerah tersebut bukanlah hak milik masyarakat lagi namun sudah berpindah tangan kepada perusahaan. Pendapatan yang diperoleh oleh warga seharihari hanya digunakan untuk mencukupi kebutuhan pokok hidup, seperti pangan. Pola konsumsi masyarakat yang hanya terkonsentrasi pada kebutuhan pangan mencerminkan keadaan masyarakat yang berada pada tingkat taraf hidup yang cukup rendah.

Kelompok Usaha Bersama (KUB) merupakan kelembagaan yang baru dibentuk pada tahun 2012 di kedua desa tersebut. Masyarakat di kedua desa sangat jarang terlibat dalam sebuah kelembagaan seperti kelompok tani, sehingga KUB merupakan kelembagaan yang ingin membangun proses belajar bersama antar masyarakat. KUB bertujuan untuk memfasilitasi masyarakat dalam menjalankan program pemberdayaan ekonomi lokal agar tercipta kehidupan yang lebih sejahtera. Pengurus KUB merupakan masyarakat desa yang juga menjadi peserta program dan dipilih secara bersama dari hasil kesepakatan seluruh peserta program yang mengikuti program pemberdayaan ekonomi lokal. Adapun sumber dana untuk operasional KUB yakni berasal dari CSR PT Pertamina yang diberikan kepada para pengurus untuk dikelola secara mandiri.

Agama Islam di Desa Balongan merupakan agama yang dianut oleh masyarakat, hanya dua orang warga lakilaki yang beragama Katholik. Hal tersebut tidak terjadi di Desa Majakerta. Di desa ini agama Islam merupakan agama satu-satunya sehingga dapat dikatakan masyarakat desa ini mono-religi. Kelembagaan sosial yang ada di lingkungan masyarakat yakni pengajian, arisan, dll. Baik di Desa Balongan maupun di Desa Majakerta, etnik yang 
sangat dominan yaitu masyarakat Indramayu, Suku JawaCirebon yang melebur. Khusus untuk di Desa Majakerta, Opinion Leader yang terdapat di desa ini cukup beragam, dimulai dari tokoh masyarakat, alim ulama, dan pegawai pemerintahan. Berkaitan dengan pelapisan sosial dalam masyarakat, di Desa Balongan dapat dilihat dari adanya tokoh masyarakat dan penduduk biasa. Dalam hal pendidikan, masyarakat di Desa Balongan dapat dikatakan lebih memiliki pendidikan yang memadai dibandingkan masyarakat di Desa Majakerta.

\section{Program Pemberdayaan Ekonomi Lokal PT Pertamina}

Komitmen PT Pertamina untuk ikut berkontribusi secara langsung dalam memajukan dan menyejahterakan masyarakat disekitarnya diwujudkan melalui pelaksanaan aktivitas Corporate Social Responsibility (CSR) serta program kemitraan dan bina lingkungan (PKBL), yang merupakan program mandatori bagi sebuah Badan usaha Milik Negara (BUMN). Salah satu bentuk komitmen CSR PT Pertamina yakni dengan dilaksanakannya program pemberdayaan ekonomi lokal. Program ini dilakukan dengan melakukan hubungan kemitraan dengan lembaga institusi, yaitu Institut Pertanian Bogor. Bentuk kolaborasi yakni kemitraan ini dilakukan karena perusahaan belum mampu melakukan upaya pemberdayaan sendiri. Hal ini dikarenakan sebelumnya tidak tercipta hubungan yang baik antara perusahaan dengan masyarakat sekitar. Program tersebut dibagi kembali menjadi beberapa jenis kegiatan di antaranya: program bantuan bidang perikanan tangkap, program budidaya lele, program peternakan yang menjadi bahasan pada penelitian ini adalah ketiga program tersebut di Desa Balongan dan Desa Majakerta.

Program perikanan tangkap yang dibentuk sejak tanggal 29 November 2011 merupakan program bantuan berbentuk pemberian alat tangkap ikan secara berkala untuk memperbaiki alat tangkap nelayan yang tidak dapat digunakan dengan baik, kemudian adanya pelatihan mesin penangkapan ikan untuk program perikanan tangkap dan penguatan interaksi antar sesama kelompok dengan adanya KUB (kelompok usaha bersama). Dalam pelaksanaan program perikanan tangkap terdapat beberapa kendala yang seringkali dialami oleh nelayan. Permasalahan yang dihadapi oleh nelayan Desa Majakerta antara lain sebagian besar nelayan masih terlilit hutang dengan bakul (tengkulak ikan) yang mengharuskan nelayan menjual hasil tangkapannya ke bakul.

Program pemberdayaan ekonomi yang juga diterapkan di Desa Balongan dan Desa Majakerta yakni program budidaya lele. Pada awalnya program ini dilakukan secara beramai-ramai dalam bentuk pemberian bantuan satu kolam untuk lima orang, namun karena hal tersebut terbukti tidak efektif dalam proses pendampingan dan menimbulkan kecemburuan sosial antar anggota kelompok akhirnya sasaran program diberikan secara individu yakni satu kolam untuk satu orang. Kendala yang dialami dalam pelaksanaan program ini yakni pemasaran hasil panen pada bakul yang cenderung membeli dengan harga rendah.

Program pemberdayaan ekonomi selanjutnya berfokus pada bidang peternakan. Latar belakang dilaksanakan program ini yakni berdasarkan hasil social mapping yang menunjukkan bahwa peternakan itik/entog merupakan salah satu potensi di ketiga desa binaan. Hal tersebut sejalan dengan tingginya permintaan telur dan entog yang dijadikan sebagai kuliner khas Kabupaten Indramayu. Pelaksanaan program peternakan ini bagi masyarakat tergolong mudah. Walaupun begitu, program ini juga tidak terlepas dari beberapa kendala. Masalah yang seringkali dialami oleh peserta program yakni pada beberapa kasus, banyak ternak yang mati dikarenakan kondisi cuaca yang cukup ekstrem (dari cuaca yang sangat panas kemudian beralih ke hujan yang sangat lebat).

\section{HASIL PENELITIAN}

\section{TINGKAT PENERAPAN PRINSIP PENGEMBANGAN MASYARAKAT DALAM PROGRAM PEMBERDAYAAN EKONOMI LOKAL}

Tingkat penerapan prinsip pengembangan masyarakat yang dilihat dari tiga indikator, yaitu tingkat kesesuaian program dengan kebutuhan peserta, tingkat pendampingan program dan tingkat partisipasi peserta dalam program pemberdayaan ekonomi lokal.

\section{Kesesuaian Program dengan Kebutuhan Peserta}

Kesesuaian program dengan kebutuhan peserta pada penelitian ini dilihat dari seberapa sesuai program CSR dalam bentuk pemberdayaan ekonomi lokal yang mencakup program perikanan tangkap, budidaya lele dan peternakan dengan apa yang menjadi kebutuhan peserta program.

Tabel 1. Jumlah dan Persentase Peserta Program Menurut Kesesuaian Program dalam Program Pemberdayaan Ekonomi Lokal PT Pertamina pada Tahun 2014

\begin{tabular}{lrrr}
\hline \multicolumn{2}{c}{ Kesesuaian Program } & Jumlah & \multicolumn{2}{c}{ Total } \\
& (jiwa) & $(\%)$ \\
\hline Rendah & & 0 & 0 \\
Sedang & & 4 & 6.7 \\
Tinggi & & 56 & 93.3 \\
& Total & 60 & 100.0 \\
\hline
\end{tabular}

Tabel 1 menunjukkan bahwa mayoritas jumlah peserta program yang menilai bahwa program CSR telah sesuai dengan apa yang mereka butuhkan sehingga dapat dikatakan tingkat kesesuaian program sesuai yakni sebesar 93.3 persen. Hal tersebut berdasarkan hasil social mapping yang telah dilakukan pada tahun 2011 oleh pihak P4W LPPM IPB. Sebagian besar masyarakat Desa Majakerta bermata pencaharian sebagai nelayan sehingga adanya program perikanan tangkap yang memberikan bantuan peralatan seperti jaring, lampu, kelip, dll memberikan cukup manfaat bagi masyarakat. Begitu pula bagi masyarakat yang menjadi peserta program budidaya lele dan peternakan yang mayoritas berada di Desa Balongan. Program pemberdayaan ekonomi lokal juga dinilai mudah dalam pelaksanaan baik itu perikanann tangkap, budidaya lele dan peternakan karena pada umumnya masyarakat telah memiliki pengalaman dan mereka memiliki motivasi yang tinggi agar mendapatkan tambahan penghasilan.

\section{Tingkat Pendampingan Program}

Pendampingan program mencakup upaya yang dilakukan 
oleh pihak pendamping teknis di lapangan untuk mendampingi, menfasilitasi, dan mendorong terjadinya proses saling belajar antara masyarakat yang menjadi peserta program.

Tabel 2. Jumlah Dan Persentase Peserta Program Menurut Pendampingan Program dalam Program Pemberdayaan Ekonomi Lokal PT Pertamina pada Tahun 2014

\begin{tabular}{|c|c|c|}
\hline $\begin{array}{c}\text { Pendampingan Pro- } \\
\text { gram }\end{array}$ & $\begin{array}{l}\text { Jumlah } \\
\text { (jiwa) }\end{array}$ & $\begin{array}{c}\text { Persentase } \\
(\%)\end{array}$ \\
\hline Rendah & 0 & 0 \\
\hline Sedang & 21 & 35 \\
\hline Tinggi & 39 & 65 \\
\hline Total & 60 & 100 \\
\hline
\end{tabular}

Tabel 2 menunjukkan bahwa mayoritas peserta program menilai bahwa pendamping teknis di lapangan telah mendampingi mereka dengan baik dalam keseluruhan pelaksanaan program pemberdayaan ekonomi lokal sehingga tingkat pendampingan program dapat dikatakan tinggi yakni sebesar 65 persen. Hal tersebut dikarenakan kerja keras pendamping lapang yang memang menetap di desa binaan PT Pertamina. Peserta program telah difasilitasi dan didorong agar terjadi proses belajar antara masyarakat. Mereka mendapatkan kesempatan dan pelatihan untuk memperbaiki kinerja mereka agar tercapai keberhasilan program. Salah satu bentuk upaya yang dilakukuan pendamping yakni memfasilitasi mereka untuk mengembangkan usaha melalui kerjasama dengan pihak-pihak terkait misalnya saja pengajuan proposal bantuan usaha kepada Dinas Pemerintah yang bersangkutan. Hal tersebut menjadi penting agar masyarakat belajar perlahanlahan untuk mandiri dan tidak terus menerus hanya ingin meminta. Berkat adanya pendampingan secara intensif, peserta program memiliki wadah untuk menyampaikan segala aspirasi mereka dan memiliki sarana untuk berdiskusi dalam rangka pemecahan masalah yang seringkali mereka alami dalam pelaksanaan program. Perlahan-lahan telah terbangun trust antara masyarakat dan pendamping program selama kurun waktu tiga tahun terakhir yang memberikan manfaat lebih besar terhadap keberhasilan program.

\section{Partisipasi Peserta dalam Program Pemberdayaan Ekonomi Lokal}

Terdapat delapan tingkatan partisipasi masyarakat, yaitu manipulation, therapy, informing, concultation, placation, partnership, delegated power dan citizen control yang kemudian dikelompokkan menjadi tiga besar derajat partisipasi yaitu non-partisipasi, tokenisme, dan citizen power (Arnstein 1969).

Tabel 3 menunjukkan bahwa mayoritas jumlah peserta program yang berada pada tingkat non-partisipasi lebih banyak sehingga tingkat partisipasinya berada pada tingkat partisipasi yang rendah yakni sebesar 66.7 persen. Secara umum, kontrol secara penuh terhadap pengimplementasian program pemberdayaan ekonomi lokal belum dapat dilakukan oleh peserta program. Rendahnya partisipasi mereka dalam program pemberdayaan ekonomi lokal disebabkan oleh banyak hal, di antaranya ialah: (1) peserta program cenderung memberikan kepercayaan kepada tokoh masyarakat yang memiliki pengaruh besar di lingkungan mereka dalam setiap pertemuan dengan pihak perusahaan, (2) pola fikir masyarakat yang masih ingin terus meminta dan diberi dana/kegiatan oleh perusahaan karena ada anggapan bahwa bantuan CSR adalah dana hibah sehingga menyebabkan mereka malas dalam menggulirkan hasil usaha untuk kembali berbudidaya, dan (3) kurang terlibatnya peserta secara keseluruhan dalam proses perencanaan sehingga rasa memiliki program masih kurang. Meskipun sudah dilakukan social mapping.

Tabel 3. Jumlah dan Persentase Peserta Program Menurut Tingkat Partisipasinya dalam Program Pemberdayaan Ekonomi Lokal PT Pertamina pada Tahun 2014

\begin{tabular}{lcrr}
\hline \multirow{2}{*}{ Partisipasi } & $\begin{array}{c}\text { Jumlah } \\
\text { (jiwa) }\end{array}$ & \multicolumn{2}{c}{ Persentase } \\
& & 40 & \\
\hline $\begin{array}{l}\text { Non Partisipasi } \\
\text { (Rendah) }\end{array}$ & & 66.7 \\
Tokenisme (Sedang) & 7 & 11.6 \\
Citizen Power (Tinggi) & 13 & 21.7 \\
Total & 60 & 100.0 \\
\hline
\end{tabular}

Tingkat Penerapan Prinsip Pengembangan Masyarakat dalam Program Pemberdayaan Ekonomi Lokal

Indikator yang digunakan untuk mengukur tingkat penerapan prinsip pengembangan masyarakat yakni tingkat kesesuaian program dengan kebutuhan masyarakat, pendampingan program, dan partisipasi yang ditunjukkan dengan keterlibatan masyarakat dalam keseluruhan proses pelaksanaan program.

Tabel 4. Jumlah dan Persentase Peserta Program Menurut Tingkat Penerapan Prinsip Pengembangan Masyarakat dalam Program Pemberdayaan Ekonomi Lokal PT Pertamina Pada Tahun 2014

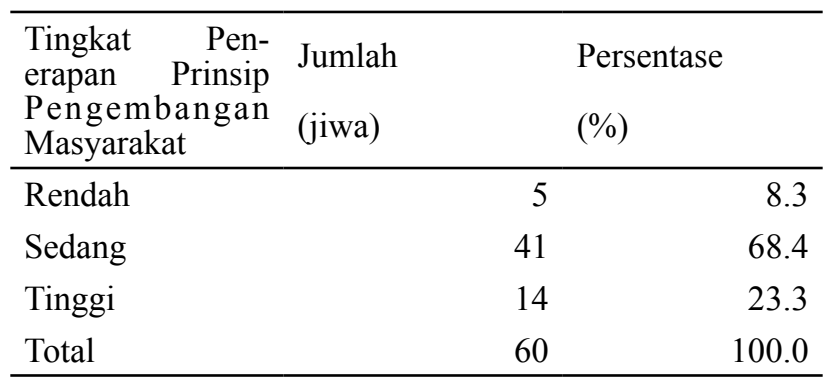

Tabel 4 menunjukkan bahwa mayoritas jumlah peserta menurut tingkat penerapan prinsip pengembangan masyarakat dalam program pemberdayaan ekonomi lokal yang dilakukan PT Pertamina bekerjasama dengan P4W LPPM IPB berada pada tingkat sedang yakni sebesar 68.4 persen. Hal tersebut berarti program CSR tersebut telah cukup menerapkan prinsip-prinsip pengembangan masyarakat dalam melaksanakan program CSR-nya. Walaupun tingkat partisipasi peserta program tergolong masih rendah, namun tingkat kesesuaian program dengan kebutuhan masyarakat beserta upaya pendampingan yang dilakukan secara intensif termasuk dalam kategori yang tinggi. Hal tersebut dikarenakan partisipasi yang terjadi masih tergolong partisipasi elitis yakni hanya elit-elit 
tertentu yang berperan aktif dalam keseluruhan pelaksanaan program. Berkaitan dengan tingginya tingkat kesesuaian dan tingkat pendampingan disebabkan adanya upaya social mapping yang telah dilakukan oleh pihak perusahaan yang bekerjasama dengan para ahli untuk merumuskan program yang tepat guna bagi masyarakat yang termasuk dalam desa binaan PT Pertamina serta pendampingan yang dilakukan secara intensif berupaya untuk menerapkan prinsip-prinsip pemberdayaan masyarakat agar tujuan kemandirian dapat tercapai.

\section{KEBERHASILAN PROGRAM CSR PT PERTAMINA}

\section{Tingkat Partisipasi Peserta dalam Kelompok Usaha Bersama (KUB)}

Partisipasi peserta program dalam kelompok usaha bersama (KUB) dilihat dari sejauh mana keterlibatannya pada tahap perencanaan, pelaksanaan dan evaluasi KUB.

Tabel 5. Jumlah dan Persentase Peserta Program Menurut Tingkat Partisipasinya dalam Kelompok Usaha Bersama Pada Tahun 2014

\begin{tabular}{lrrr}
\hline $\begin{array}{l}\text { Tingkat Partisipasi da- } \\
\text { lam KUB }\end{array}$ & $\begin{array}{l}\text { Jumlah } \\
\text { (jiwa) }\end{array}$ & \multicolumn{2}{c}{ Persentase } \\
\hline Non Partisipasi & 52 & 86.7 \\
(Rendah) & & \\
Tokenisme (Sedang) & 2 & 3.3 \\
Citizen Power (Tinggi) & 6 & 10.0 \\
Total & 60 & 100.0
\end{tabular}

Tabel 5 menunjukkan bahwa mayoritas jumlah peserta program menurut tingkat partisipasinya dalam kelompok usaha bersama (KUB) berada pada tingkat partisipasi non-partisipasi (rendah) yakni sebesar 86.7 persen. Secara umum, peserta program belum terlibat secara keseluruhan dalam proses pelaksanaan KUB. Rendahnya partisipasi mereka dalam kelembagaan kelompok usaha bersama (KUB) disebabkan oleh banyak hal, di antaranya ialah: (1) ketua kelompok yang tidak melakukan transparansi dalam penggunaan dana KUB. (2) Menurunnya tingkat kepercayaan beberapa anggota terhadap ketua mereka sehingga yang sering ikut berpartisipasi dalam setiap rapat hanyalah orang-orang tertentu yang menjadi pengikut serta selalu mematuhi perkataan pemimpin mereka. (3) pelaksanaan KUB yang belum berjalan kembali karena sangat tergantung dengan bantuan modal dari PT Pertamina untuk beroperasi.

\section{Tingkat Pendapatan Individu Per Tahun}

Tingkat pendapatan pada penelitian ini dilihat penghasilan berupa uang yang diperoleh tiap individu setelah dikurangi biaya-biaya yang dikeluarkan dalam kurun waktu satu tahun dari pelaksanaan program pemberdayaan ekonomi lokal yang terdiri atas program perikanan tangkap, program budidaya lele, dan peternakan.

Tabel 6 menunjukkan bahwa mayoritas jumlah peserta program (71.7 persen) berada pada tingkat pendapatan rendah dan sedang Kondisi tingkat pendapatan peserta program yang relatif rendah dan sedang dipengaruhi oleh beberapa hal yakni: (1) konsep usaha perikanan tangkap, budidaya lele dan peternakan belum mampu memberikan keuntungan yang sangat besar jika hanya bergantung pada modal yang diberikan. (2) Keterikatan peserta program dengan bakul ikan (tengkulak) akibat pinjaman uang yang diberikan menyebabkan mereka harus menjual hasil usaha mereka ke bakul, sedangkan harga beli yang ditetapkan bakul sangat rendah sehingga tidak memberi keuntungan bagi masyarakat, dan (3) pola pikir dan karakter masyarakat yang kurang gigih dalam berusaha dan hanya mengharapkan kiriman uang dari keluarga mereka yang bekerja sebagai TKI atau TKW di luar negeri.

Tabel 6. Jumlah dan Persentase Peserta Program Menurut Tingkat Pendapatan dari Pelaksanaan Program Pemberdayaan Ekonomi Lokal PT Pertamina Pada Tahun 2014

\begin{tabular}{lcr}
\hline Tingkat Pendapatan & $\begin{array}{c}\text { Jumlah } \\
\text { Persentase }\end{array}$ \\
(Rata-rata pertahun) & (jiwa) & (\%) \\
\hline Rendah & 22 & 36.7 \\
$(\leq$ Rp18 041 977) & & \\
Sedang & 21 & 35.0 \\
$($ Rp18 041 977<x $>$ Rp46 691 & & \\
440) & & \\
Tinggi & 17 & 28.3 \\
( $\geq$ Rp46 691 440) & & \\
Total & & \\
\hline
\end{tabular}

\section{Tingkat Keragaman Nafkah}

Tingkat keragaman nafkah dilihat dari seluruh pekerjaan yang dilakukan oleh responden dalam rangka memenuhi kebutuhan hidup rumahtangganya. Pengkategorian keragaman nafkah berdasarkan jumlah sumber nafkah manakah yang selama ini dilakukan oleh peserta program.

Tabel 7. Jumlah dan Persentase Peserta Program Menurut Tingkat Keragaman Nafkah Setelah Mengikuti Program Pemberdayaan Ekonomi Lokal PT Pertamina Pada Tahun 2014

\begin{tabular}{llrr}
\hline $\begin{array}{l}\text { Tingkat Keragaman } \\
\text { Nafkah }\end{array}$ & $\begin{array}{l}\text { Jumlah } \\
\text { (jiwa) }\end{array}$ & \multicolumn{2}{c}{ Persentase } \\
& & 0 & 0 \\
Rendah & 17 & 28.3 \\
Sedang & 43 & 71.7 \\
Tinggi & 60 & 100.0 \\
Total & & 0 & \\
\hline
\end{tabular}

Tabel 7 menunjukkan bahwa mayoritas jumlah peserta berada pada tingkat keragaman nafkah tinggi. Artinya, masyarakat di Desa Majakerta dan Desa Balongan yang termasuk dalam peserta program pemberdayaan ekonomi lokal PT Pertamina lebih banyak memiliki sumber nafkah dari sektor pertanian. Sektor pertanian yang dimaksud dalam penelitian ini adalah pengertian pertanian dalam 
konteks luas yang mencakup perairan, budidaya, pertanian padi sawah, peternakan, dan usaha-usaha membudidayakan hasil alam untuk dikelola. Hasil penelitian juga menunjukkan bahwa sangat jarang masyarakat yang menggantungkan hidupnya pada kegiatan industri dan sebagian lainnya memilih untuk berdagang atau menjadi buruh proyek. Namun secara keseluruhan, sumber nafkah utama masyarakat masih dari sektor pertanian

\section{TINGKATPENERAPANPRINSIPPENGEMBANGAN MASYARAKAT DAN HUBUNGANNYA DENGAN KEBERHASILAN PROGRAM CSR PT PERTAMINA}

Hubungan Tingkat Penerapan Prinsip Pengembangan Masyarakat dengan Tingkat Partisipasi Peserta dalam Kelompok Usaha Bersama

Hubungan tingkat penerapan prinsip pengembangan masyarakat dalam program pemberdayaan ekonomi lokal dengan tingkat partisipasi peserta dalam kelompok usaha bersama (KUB) diuji dengan menggunakan uji statistik korelasi non-parametrik rank Spearman karena kedua variabel tersebut memiliki data dengan skala ordinal. Dari hasil uji korelasi diperoleh nilai koefisien korelasi antara variabel tingkat penerapan prinsip pengembangan masyarakat dengan tingkat partisipasi peserta dalam KUB sebesar 0.354. Berdasarkan data tersebut maka dapat dikatakan bahwa kedua variabel tersebut memiliki hubungan yang moderat. Selain itu, diperoleh juga nilai signifikan hitung sebesar 0.006 (0.05), sehingga $\mathrm{H} 0$ ditolak dan $\mathrm{H} 1$ diterima. Artinya, tingkat penerapan prinsip pengembangan masyarakat dalam program CSR pemberdayaan ekonomi lokal berhubungan positif dengan tingkat partisipasi masyarakat dalam KUB.

Tabel 8. Jumlah dan Persentase Peserta Program Menurut Tingkat Penerapan Prinsip Pengembangan Masyarakat dalam Program CSR Pemberdayaan Ekonomi Lokal dan Tingkat Partisipasi Peserta Dalam Kelompok Usaha Bersama Pada Tahun 2014

\begin{tabular}{|c|c|c|c|}
\hline \multirow{3}{*}{$\begin{array}{l}\text { Tingkat Partisi- } \\
\text { pasi } \\
\text { dalam KUB }\end{array}$} & \multicolumn{3}{|c|}{$\begin{array}{l}\text { Tingkat Penerapan Prinsip } \\
\text { Pengembangan Masyarakat }\end{array}$} \\
\hline & Rendah & Sedang & Tinggi \\
\hline & $\mathrm{n}(\%)$ & $\mathrm{n}(\%)$ & $\mathrm{n}(\%)$ \\
\hline $\begin{array}{l}\text { Non-partisipasi } \\
\text { (Rendah) }\end{array}$ & $5(100.00)$ & $38(92.68)$ & $9(64.29)$ \\
\hline $\begin{array}{l}\text { Tokenisme } \\
\text { (Sedang) }\end{array}$ & 0 & $1(2.44)$ & $1(7.14)$ \\
\hline $\begin{array}{l}\text { Citizen power } \\
\text { (Tinggi) }\end{array}$ & 0 & $2(4.88)$ & $4(28.57)$ \\
\hline $\begin{array}{l}\text { Total } \\
\text { n (\%) }\end{array}$ & $5(100.00)$ & $41(100.00)$ & $\begin{array}{l}14 \\
(100.00)\end{array}$ \\
\hline
\end{tabular}

Tabel 8 menunjukkan bahwa jumlah peserta program yang menilai tingkat penerapan prinsip pengembangan masyarakat dalam program CSR tinggi dan memiliki tingkat partisipasi tinggi (citizen power) lebih banyak dibanding lainnya. Terdapat kecenderungan bahwa peserta program yang menilai tingkat penerapan prinsip pengembangan masyarakat tinggi memiliki tingkat partisipasi yang tinggi (citizen power) dalam kelompok usaha bersama (KUB). Hal tersebut disebabkan mereka yang menilai tingkat penerapan prinsip pengembangan masyarakat yang tinggi cenderung memiliki motivasi yang lebih tinggi untuk mengupayakan terbentuknya kelompok usaha bersama (KUB).

\section{Hubungan Tingkat Penerapan Prinsip Pengembangan Masyarakat dengan Tingkat Pendapatan Peserta Program}

Dari hasil uji korelasi diperoleh nilai koefisien korelasi antara variabel tingkat penerapan prinsip pengembangan masyarakat dengan tingkat pendapatan peserta program sebesar 0.064. Berdasarkan data tersebut maka dapat dikatakan bahwa kedua variabel tersebut memiliki hubungan yang kurang berarti. Selain itu, diperoleh juga nilai signifikan hitung sebesar 0.628 (0.05), sehingga $\mathrm{H} 0$ diterima dan $\mathrm{H} 1$ ditolak. Hasil tersebut menunjukkan tingkat penerapan prinsip pengembangan masyarakat dalam program CSR pemberdayaan ekonomi lokal tidak berhubungan positif dengan tingkat pendapatan peserta program.

Tabel 9. Jumlah dan persentase peserta program menurut tingkat penerapan prinsip pengembangan masyarakat dalam program CSR pemberdayaan ekonomi lokal dan tingkat pendapatan peserta program CSR pada tahun 2014

\begin{tabular}{lccc}
\hline \multirow{2}{*}{$\begin{array}{l}\text { Tingkat Pendapa- } \\
\text { tan }\end{array}$} & \multicolumn{3}{c}{ Tingkat Penerapan Prinsip } \\
Peserta & \multicolumn{2}{c}{ Pengembangan Masyarakat } \\
\cline { 2 - 4 } CSR & Rendah & Sedang & Tinggi \\
& $\mathrm{n}(\%)$ & $\mathrm{n}(\%)$ & $\mathrm{n}(\%)$ \\
\hline Rendah & $2(40.00)$ & $15(36.59)$ & $5(35.71)$ \\
Sedang & $2(40.00)$ & $15(36.59)$ & $4(28.58)$ \\
Tinggi & $1(20.00)$ & $11(26.82)$ & $5(35.71)$ \\
Total & & & 14 \\
$\mathrm{n}(\%)$ & $5(100.00)$ & $41(100.00)$ & $(100.00)$ \\
\hline
\end{tabular}

Tabel 9 menunjukkan bahwa jumlah peserta program yang menilai tingkat penerapan prinsip pengembangan masyarakat sedang dan memiliki tingkat pendapatan tinggi lebih banyak dibanding lainnya. Namun, tidak terdapat kecenderungan bahwa peserta program yang menilai tingkat penerapan prinsip pengembangan masyarakat tinggi akan memiliki tingkat pendapatan yang juga tinggi. Hal tersebut disebabkan mereka yang menilai tingkat penerapan prinsip pengembangan masyarakat dalam program pemberdayaan ekonomi lokal yang tinggi sebagian besar tidak melakukan upaya tambahan untuk meningkatkan usaha mereka dengan cara mencari pinjaman modal dari pihak lain.

\section{Hubungan Tingkat Penerapan Prinsip Pengembangan Masyarakat dengan Tingkat Keragaman Nafkah Peserta Program}

Dari hasil uji korelasi diperoleh nilai koefisien korelasi antara variabel tingkat penerapan prinsip pengembangan masyarakat dengan tingkat keragaman nafkah peserta 
program sebesar 0.168. Berdasarkan data tersebut maka dapat dikatakan bahwa kedua variabel tersebut memiliki hubungan yang lemah. Selain itu, diperoleh juga nilai signifikan hitung sebesar $0.199(0.05)$, sehingga $\mathrm{HO}$ diterima dan $\mathrm{H} 1$ ditolak. Hasil tersebut menunjukkan tingkat penerapan prinsip pengembangan masyarakat dalam program CSR pemberdayaan ekonomi lokal tidak berhubungan positif dengan tingkat keragaman nafkah peserta program.

Tabel 10 menunjukkan bahwa mayoritas jumlah peserta program yang menilai tingkat penerapan prinsip pengembangan masyarakat sedang dan memiliki tingkat keragaman nafkah tinggi lebih banyak yakni sebesar 32 persen. Dari tabel dapat dilihat bahwa tidak terdapat kecenderungan bahwa peserta program yang menilai tingkat penerapan prinsip pengembangan masyarakat tinggi akan memiliki tingkat keragaman nafkah yang juga tinggi. Hal tersebut dikarenakan responden yang mengikuti program pemberdayaan ekonomi lokal pada umumnya telah bermata pencaharian di bidang pertanian khususnya dalam hal perikanan tangkap, budidaya lele dan peternakan. Tingkat keragaman nafkah dinilai tinggi karena sebagian besar sumber nafkah responden yang mengikuti program berasal dari pertanian dalam arti luas yakni mencakup perikanan, peternakan, dll.

Tabel 10. Jumlah dan Persentase Peserta Program Menurut Tingkat Penerapan Prinsip Pengembangan Masyarakat dalam Program CSR Pemberdayaan Ekonomi Lokal dan tingkat keragaman nafkah peserta program CSR pada tahun 2014

\begin{tabular}{lccc}
\hline \multirow{2}{*}{$\begin{array}{l}\text { Tingkat Kerag- } \\
\text { aman Nafkah }\end{array}$} & \multicolumn{3}{c}{ Tingkat Penerapan Prinsip } \\
Peserta Program & Rengembangan Masyarakat \\
\cline { 2 - 4 } CSR & $\mathrm{n}(\%)$ & $\mathrm{n}(\%)$ & $\mathrm{n}(\%)$ \\
\hline Sedang & $2(40.00)$ & $9(21.96)$ & $7(50.00)$ \\
Tinggi & $3(60.00)$ & $32(78.04)$ & $7(50.00)$ \\
Total n $(\%)$ & $5(100.00)$ & $41(100.00)$ & $(100.00)$ \\
\hline
\end{tabular}

\section{KESIMPULAN DAN SARAN}

\section{Kesimpulan}

1. Program CSR yang diimplementasikan PT Pertamina bekerjasama dengan P4W LPPM IPB telah cukup menerapkan prinsip-prinsip pengembangan masyarakat dalam upaya memberdayakan masyarakat berbasiskan sumberdaya lokal yang ada disekitar mereka.

2. Tingkat keberhasilan program CSR masih tergolong rendah. Hal ini ditunjukkan dengan masih rendahnya tingkat partisipasi peserta dalam kelompok usaha bersama (KUB). Begitu pula dengan tingkat pendapatan peserta program yang masih tergolong rendah. Namun, tingkat keragaman nafkah peserta yang mengikuti program secara keseluruhan dinilai tinggi.
3. Pada program CSR pemberdayaan ekonomi lokal, terdapat kecenderungan semakin tinggi tingkat penerapan prinsip pengembangan masyarakat maka semakin tinggi tingkat keberhasilan program CSR. Tingkat penerapan prinsip pengembangan masyarakat menentukan tingkat partisipasi masyarakat dalam KUB, namun tidak menentukan tingkat pendapatan dan tingkat keragaman nafkah peserta program.

\section{Saran}

1. Peserta program perlu dilibatkan dalam keseluruhan proses pelaksanaan program khususnya dalam perencanaan program CSR agar masyarakat merasa memiliki program, mampu menyusun sesuai dengan kebutuhan mereka, dan mengevaluasi program agar terus berkelanjutan untuk meningkatkan partisipasi peserta program.

2. Perlu diadakan kegiatan penguatan kelompok dalam keseluruhan program agar kelembagaan kelompok usaha bersama dapat terus berkelanjutan dan mendorong terjadinya partisipasi anggota KUB.

3. Strategi pemberdayaan yang dilakukan oleh CSR PT Pertamina bekerjasama dengan P4W LPPM IPB harus dikembangkan dalam bentuk pengolahan hasil usaha yang melibatkan tidak hanya peserta program namun juga keluarganya agar meningkatkan keberdayaan masyarakat. Peserta program juga didorong untuk berinisiatif dalam mengembangkan sendiri usaha mereka agar dapat berkembang dan menguntungkan sehingga memberikan tambahan pendapatan.

\section{DAFTAR PUSTAKA}

Ambadar, J. 2008. CSR dalam Praktik di Indonesia. Jakarta (ID): PT Elex Media Komputindo.

Anatan, L. 2010. Corporate Social Responsibility (CSR) : Tinjauan teoritis dan Praktis di Indonesia. Jurnal Manajemen. [Internet]. [diunduh 11 November 2013]. 13(2). Dapat diunduh dari: http://majour. maranatha.edu/index.php/jurnal manajemen/ article/view/220/pdf

Anggraeni, YD. 2013. Tingkat Keberhasilan Program Corporate Social Responsibility "Water AccessSanitation and Hygiene" PT Aqua Golden Mississippi Citereup. Skripsi. [Internet]. [diunduh 29 November 2013]. Dapat diunduh dari: http:// repository.ipb.ac.id/handle/123456789/66073

Arnstein S. 1969. A Ladder of Citizen Participation. JAIP [35-4]: halaman 216-224.

Dharmawan AH. 2007. Sistem Penghidupan dan Nafkah Pedesaan: Pandangan Sosiologi Nafkah (livelihood sociology) Mahzab Barat dan Mahzab Bogor. Sodality. Volume 01 Nomor 02. [Internet].[diunduh 20 Maret 2014]. Dapat diunduh dari: http:// jurnalsodality.ipb.ac.id/index.php/component/ sodality/?id=86\&task=view Hal 169-192.

Ife JW. 1995. Community Development: Cerating Community Alternatives. Melbourne: Longman Australia. 
Khusnul, E. 2009. Program Pemberdayaan CSR Exxonmobil dalam Peningkatan Kesejahteraan Sosial di Desa Gayam Kecamatan Gayam Kabupaten Bojonegoro. Jurnal Trunojoyo. [Internet]. [diunduh 11 November 2013]. 11(2). Dapat diunduh dari: http://pta.trunojoyo.ac.id/ uploads/journals/090521100016/090521100016.pdf

Mapisangka, A. 2009. Implementasi CSR terhadap Kesejahteraan Hidup Masyarakat. Jurnal Ekonomi dan Sosial Pembangunan. [Internet]. [diunduh 27 Sepetember 2013]. 01(1). Dapat diunduh dari: http://fe.um.ac.id/wpcontent/uploads/ 2009/09/ ANDI_M-CSR1.pdf

Mubyarto. 2000. Membangun Sistem Ekonomi. BPFE.

Nasdian, FT. 2014. Pengembangan Masyarakat. Jakarta [ID]: Yayasan Obor Indonesia

PT Pertamina. 2011. Strengthening Our Commitment. Laporan Keberlanjutan. [Internet]. [diunduh 7 Maret 2014]. Dapat diunduh dari: http://www. pertamina.com/media/bb465a99-5106-40b2bf $11-\mathrm{f} 2928221921 \mathrm{f} / \mathrm{SR} \% 20$ pertamina $\% 20$ 2011_22jan13.pdf

Rahmawati A. 2010. Efektivitas Organisasi dan Implementasi Program Corporate Social Responsibility PT. Indocement Tunggal Prakarsa Tbk. [Skripsi]. Bogor [ID]: Institut Pertanian Bogor.

Rosika, AA. 2011. Efektivitas dan Dampak Program Community Based Development Bali Sejahtera dalam Peningkatan Kesempatan Kerja dan Pendapatan Rumah Tangga Miskin di Kabupaten Gianyar. [Internet]. [diunduh 20 Maret 2014]. Dapat diunduh dari: http://www.pps.unud.ac.id/thesis/ pdf thesis/unud-283-1379376497-bab\%20i,ii,iii,iv. pdf

Susiloadi, P. 2008. Implementasi Corporate Social Responsibility untuk Mendukung Pembangunan Berkelanjutan. Jurnal Spirit Publik. [Internet]. [diunduh 13 November 2013]. 04(2). Dapat diunduh dari: http://fisip.uns.ac.id/publikasi/sp4_2_priyanto. pdf 